\title{
Knowledge of Management and Work Environment Principal of Madrasah Ibtidaiyah In Creating Service Quality In Islamic Boarding School
}

\author{
Musifudin ${ }^{1, a^{*}, \text { Rugaiyah }}{ }^{1, b}$, Maruf Akbar ${ }^{1, c}$ and Muhamad Suhardi,, $\mathrm{d}$ \\ ${ }^{1}$ Department of Education Management, Universitas Negeri Jakarta, Jakarta Timur, 13220, Indonesia \\ shief70@gmail.com; rugaiyah@unj.ac.id; marufakbar@unj.ac.id; \\ ${ }^{*}$ Corresponding Author \\ Whatsapp number: [+62-819 1796 9169]
}

How to Cite : Musifudin, M. Rugaiyah, R., Akbar, M., Suhardi, M. (2019). Knowledge of Management and Work Environment Principal of Madrasah Ibtidaiyah In Creating Service Quality In Islamic Boarding School. International Journal for Educational and Vocational Studies, 1 (2), 100-103.

\section{ARTICLE HISTORY}

Received:3 May 2019

Revised: 23 May2019

Accepted: 29 May 2019

\section{KEYWORDS}

Knowledge Management, Work Environment,

School Principal

\begin{abstract}
This study aims to investigate the quality of service of the head of the Islamic elementary school in terms of the level of management knowledge and work environment. This research is a quantitative study carried out in the East Lombok Madrasah in East Nusa Tenggara Province with the number of respondents being 65 heads of Islamic schools. Data were obtained through interviews, review of documents and literal scale questionnaires that had been standardized using Confirmatory Factor Analysis (CFA) with the Lisrel 8.80 full version program. For data analysis using path analysis techniques (path analysis). The findings of this study reveal that the knowledge of school principals influences the quality of service. Thus the high and low quality of service of the head of the Islamic school can be influenced by the level of knowledge of management. The results of this study contribute to schools that have low-quality leadership services to serve as a basis for improvement.
\end{abstract}

This is an open access article under the CC-BY-SA license.

\section{INTRODUCTION}

The Principal of islmaic boarding school is a teacher who is given the responsibility to lead and regulate the implementation of quality education (RI Minister of Education Regulation : 2018) The head of the madrasa has a very important role in mobilizing and harmonizing the educational resources available at the madrasa and using it according to needs (Nurbaya, Harun, \& Djailani. : 2015). To make it happen the headmaster must have sufficient knowledge about management and be supported by a conducive work climate. With the knowledge of the headmaster's management, it will be easier to direct, motivate, and lead the members of the madrasa properly (Oztekin.,at. all : 2015).

Their knowledge management functions to make, identify and manage the organization for long-term benefits (Heier, Hauke: 2004). Knowledge is integrated as one of the key components of success in achieving goals and creating new knowledge in planning, feeling, interpreting, and responding to new opportunities and threats (Ahmad Sahas; Nur Falah \& Arik Praseteya: 2017). Integration of knowledge in teams is a very import- ant attitude as a form of exploitation and can generate agreement and harmony to realize the intended goals. So that the existence of management knowledge describes the awareness and systematic handling of knowledge resources and applications targeted in certain organizations (Djafri, Novianty: 2015).

In the context of regional autonomy, the head of the madrasa must be able to provide good service and be able to carry out cooperation with various parties both internally and externally through programs that are carried out in a planned and gradual manner without being burdened by the interventions of any party (Isabel Prieto; Perez, Natalia Martín Cruz \& Víctor Martín: 2016). The creation of madrasah chief services is the front line in realizing quality madrasas. The quality of education services in Madrasahs is largely determined by the managerial ability of principals in implementing good administrative arrangements, and teacher performance is largely determined by the professional abilities possessed by the principals, work motivation, and commitment to their duties. 
In Madrasah Ibtidaiyah (MI) in the neighborhood of Nahdlatul Wathan (NW) Islamic Boarding School in East Lombok Regency based on the results of interviews with teachers, information was obtained that the quality of services built by the madrasa head was still low. The low quality of service is due to insufficient management knowledge. Maryono stated that this is in line with (Jarfi, Louwis : 2016). that the ability of madrasa principals who are still low in managing madrasas will have an impact on the low quality of education. In addition to management knowledge, a less conducive work environment also has an impact on the low quality of school principals (Heinz, M. \&: 2007).

On the other hand, madrasah head recruitment is carried out with a pointing system directly from the foundation without selection. This has an impact on the management of the education unit management system in Islamic boarding schools. The head of MI plays a very dominant role in determining policies technically so that leadership emerges with authoritarian characteristics that result in teachers and students being less communicative and productive. The subjectivity of the leadership of the Islamic boarding school in appointing the head of the madrasa on the basis of kinship considerations, emotional closeness, giving birth to a madrasa head who lacks experience and knowledge.

To realize the quality standards for implementing education in MI schools, formally the role of the headmaster is very important in it and has authority, namely as a manager so that it can influence the staff, both directly and indirectly. Referring to various theoretical and empirical approaches, one type of Madrasah head leadership that can be used is the type of transformational leadership. Madrasah heads also have a very large role in developing the quality of services in these educational institutions.

Based on the identification of problems and relevant theoretical studies above, it can be decided that in this study, researchers conducted an investigation into the quality of service of principals in the madrasah ibtidaiyah (MI) by reviewing the level of management knowledge held by the MI chief so that they can determine attitudes for improvement and sustainability. in the NW boarding school in East Lombok Regency.

\section{METHODS}

This research is quantitative research conducted at madrasah ibtida'iah in the NW boarding school in East Lombok Regency. The sample in this study was the head of the madrasa with 65 people. Furthermore, data collection is carried out through interview techniques, document reviews, and questionnaires with lust scale. The path analysis that will be used in this study is Path Analysis.[17] While the calculation of path analysis and path model testing is done using the help of SPSS and or LISREL 8.72 Full Version software programs.

\section{RESULTS AND DISCUSSION}

\section{Results}

Based on the results of the analysis compared with the magnitude of the value of Fcount with Ftable which is Fcount $=11.02$ greater than Ftable $=2,76$ at the confidence level of 0.05 , it was concluded that Ho refused. This shows that there is a linear relationship between management knowledge and the work environment towards the quality of service of the principal. Thus the resulting regression model can be declared feasible or correct and can be presented in the following table 1 .

Table 1. ANAVA

\begin{tabular}{|c|c|c|c|c|c|c|}
\hline \multirow{2}{*}{$\begin{array}{l}\text { Resouces } \\
\text { Varians }\end{array}$} & \multirow{2}{*}{$\mathrm{db}$} & \multirow{2}{*}{ JK } & \multirow{2}{*}{ RJK } & \multirow{2}{*}{$F_{\text {hit }}$} & \multicolumn{2}{|l|}{$\mathrm{F}_{\text {tabel }}$} \\
\hline & & & & & 0,05 & 0,01 \\
\hline Regression & 3 & 4637,17 & 1545,72 & \multirow{2}{*}{11,02} & \multirow{2}{*}{2,76} & \multirow{2}{*}{4,13} \\
\hline Residu & 61 & 8556,98 & 140,28 & & & \\
\hline Total Reduced & 64 & 13194,15 & - & - & - & - \\
\hline
\end{tabular}

The correlation coefficient between the above variables can be used to determine the path coefficient, namely p41 $=0.23$, and $\mathrm{p} 42=0.28$.

The significance or significance of the path coefficients above can be determined by comparing the value of the pij path coefficient with the price of 0.05 , namely if the value obtained is $>0.05$, the path coefficient is considered significant or significant. This can also be done through statistical tests $t$ (beta test). Furthermore, the results of hypothesis testing calculations that have been formulated can be specified in table2.

Table 2. Pathway Test at a 0.05

\begin{tabular}{|c|c|c|c|c|c|}
\hline \multirow{2}{*}{ No. } & \multirow{2}{*}{ Statistics Key } & \multirow[t]{2}{*}{$(\beta)$} & \multicolumn{3}{|c|}{ Pathway Test at a 0.05} \\
\hline & & & $t_{\text {hitg }}$ & ttabel & Conclusion \\
\hline 1 & $\begin{array}{l}Y \text { on } \quad X 1 \\
H_{0}: \beta_{41} \leq 0 \\
H_{1}: \beta_{41}>0\end{array}$ & 0,23 & 3,67 & 1,996 & $\begin{array}{l}\text { Positive Direct } \\
\text { Influence }\end{array}$ \\
\hline 2 & $\begin{array}{l}Y \text { on } X 2 \\
H_{0}: \beta_{42} \leq 0 \\
H_{1}: \beta_{42}>0\end{array}$ & 0,28 & 3,89 & 1,996 & $\begin{array}{l}\text { Positive Direct } \\
\text { Influence }\end{array}$ \\
\hline
\end{tabular}

\section{Discussion}

This study can reveal the influence of management knowledge, work environment and work commitment on service quality In accordance with the results of the data that have been obtained in this study below, we will explain the description of the research problems in succession as follows:

1. There is a Direct Effect of Management Knowledge on the Quality of Service of Madrasah Heads.

The knowledge of the headmaster about his duties and functions as a manager can assist them in carrying out managerial duties to the maximum so that they result in 
quality services. This statement is based on the results of the analysis, namely count 3.67 $>$ table $=1.996$ at $\alpha=0.05$, which means that Madrasah heads who have sufficient management knowledge will be better at providing services. The results of this study are also supported by Djafri (2016) that there is an influence of management knowledge and emotional intelligence of the Madrasah head on the effectiveness of the leadership of the Madrasah head itself, where the leadership of the Madrasah head determines the realization of quality services. This means that the size commonly used to recognize the effectiveness of Madrasah head leadership is the extent to which Madrasah community members feel satisfied with the services provided by the head of the Madrasah itself.

On the other hand, the knowledge of the headmaster's management is not only obtained through formal learning but can also be obtained through work experience. The intended work experience is the period of work that is owned, the results of discussions with other people, training that is often followed and the results of the independent learning he does.

This is also expressed by Hahn \& Subramani, Nonaka, Quinn, Anderson, \& Finkelstein; Hauke Heier (2004) that knowledge management is the process of capturing an organization's collective expertise and intelligence and uses it to promote innovation through continuous organizational learning. A person's ability to understand something he does can help him in promoting innovation through a continuous learning process. This is because someone who has knowledge of management is believed to have collective expertise and intelligence that can help him in creating quality services. Even the knowledge itself can be used as a basis by someone in taking actions or actions that are effective in achieving organizational goals including madrasas / Madrasas.

\section{There is a Direct Effect of the Work Environment on the Quality of Service of Madrasah Heads.}

The work environment of the madrasa principals that are comfortable, organized, clean, beautiful, attractive will greatly determine the provision of quality services by the principals. This is based on the results of the analysis and obtained results where thing $=3.89>\mathrm{t}$ table $=1.996$ at $\alpha=0.05$ means that the better the work environment will be the more quality services provided to the civitas madrasah. The work environment in question involves noise levels, air quality, working hours, additional facilities provided, and work relations between the madrasa head and his staff. The principals can work well and effectively if supported by the physical condition of the madrasa that is good, not too noisy, the air quality is supportive, working hours are right/suitable or not overloaded, and other facilities that support, and harmonious relations between the headmaster with his staff.
The work environment is not only related to the physical but also related to non-physical such as emotions/feelings at work, internal conflicts, competition, and others. This work environment is not only related to the condition of facilities and infrastructure but also related to the atmosphere/situation in which a person works which is then interpreted as a climate. Even the work environment also concerns the leadership climate of the madrasa head itself or the mood of the madrasa head about the conditions around him.

This finding is in line with Kurniawan (2007) that the work environment has a positive and significant contribution to performance. The results of this study clarify the importance of a good work environment for anyone, including the headmaster, because this can contribute positively to the quality of work or services that will be provided to others. Davidson and Fielden (2003) stated that the work environment can influence employee attitudes and perceptions, as well as other performance outcomes. A person's work environment will greatly affect one's attitude and perception of his work. This attitude and perception can be used as a measure of providing quality services to others. Meanwhile, Les Gallay interpreted the work environment, including Madrasah environment, as one of the key factors towards effective Madrasah.

\section{CONCLUSION}

1. Management knowledge has a positive direct effect on service quality. This means that the higher the headmaster's knowledge about management will be the more quality services provided to all customers both internal and external customers.

2. Work Environment has a positive direct effect on Service Quality. This means that a work environment that is conducive or good will result in good service quality, or an improvement in the work environment will result in the quality of the service of the headmaster.

\section{Acknowledgements}

An unlimited thank you to the State University of Jakarta, which has given the opportunity to complete studies in the education management department and is an unforgettable thank you to all the madrasa principals who have taken the time to assist in the process of completing the final project.

\section{REFERENCES}

RI Minister of Education Regulation 2018. (2018). About the Assignment of Teachers as Principals. Regulation of the Minister of Education and Culture of the Republic of Indonesia, Number 6. Chapter I Article 1. h. 3 . 
Nurbaya, Harun, \& Djailani. (2015). Principal Leadership Style in Improving Teacher Performance. Journal of Postgraduate Education Administration at Syiah Kuala University, Volume 3, No. 2, May. ISSN 2302-0156. Pp. 116 - 127. p.161.

Oztekin, Asil; Delen, Dursun; Zaim, Halil; Turkyilmaz, Ali; Zaim, Selim; (2015). The In uence of Knowledge Management on Financial and Non-Financial Performance. Journal of Information \& Knowledge Management, World Scientific Publishing Co. DOI: 10.1142 / S0219649215500136. Vol. 14, No. 2, p.12.

Heier, Hauke. (2004). Change Pradigms in the Settings of Knowledge Management Systems. Verlag: Deutscher University.

Ahmad Sahas; Nur Falah \& Arik Praseteya. (2017). Drivers know that they have been treated to employees and company employees. Journal of Business Administration (JAB), Vol. 50 No. September 4th. Busines Administration .studentjournal.ub.ac.id p.193.

[Djafri, Novianty. (2015). Effect of Knowledge Management and Emotional Intelligence on the Effectiveness of Leadership of High School Heads in Gorontalo Province. National Innovative Research IV Seminar, V. 3, November. h. 189.

http://eproceeding.undiksha.ac.id/index.php/senari/a rticle/view/505.

Pastor, Isabel Prieto; Perez, Natalia Martín Cruz \& Víctor Martín. (2016). Social Capital, Knowledge Integration and Ambience of Project-Based Teams in R \& D Organizations. XXVI Congreso Nacional De Acede, 20.

Jarfi, Louwis. (2016). Effect of Satisfaction, Work Experience, and Welfare on Work Commitments of Public High School Teachers in Manokwari District. Journal of Educational Management Accountability, volume 4, No. 1. 43.

Heinz, M. \&. (2007). Implementation of knowledge management in organizations. Springer Science + Business Media., (71). DOI 10.1007/ s11519-007-0006-0. https://www.researchgate.net/publication/301895434

Rokhmaniyah. (2017). Effect of Management Knowledge on School Principal Performance.

Proceedings of the National Educational Innovation, ISBN: 978-602-6977-53-3. h.363.

Raihani. (2012). Report on Multicultural Education in Pesantren. Journal of Comparative and International Education, Vol.42, No.4:585-605.

Kurniawan, Bayu; (2007). Job Satisfaction Moderates the Effect of Work Environment and Principal
Leadership on Teacher Performance. National Seminar and 2017 Call for Paper, Human Resource Development Strategy Through Scientific, Journal Publication in Responding to RI Minister of Research, Technology and Higher Education No.20 of 2017, 490.

Marilyn, Davidson J \& Sandra, Fielden L. (2003). Individual Diversity and Psychology in Organizations. . England: John Wesley \& Sons.

Susilawati. (2015). Effect of Teacher Service Quality and Transformational Leadership of Principals on Elementary School Quality. Journal of Educational Administration, Vol. XII, April 1. h.181.

Arsyad, Arfan . (2016). "Influence of Knowledge of Management, Principals' Attitude, and Effectivenjess of Prodira Towards School Performance in Gorontalo Provincial . Jurnal Ilmiah Educational Management, Vol.7, Manajemen Pendidikan Program Pascasarjana UNJ. 